\title{
Interferon gamma Profile in Egyptian Infants with Respiratory Syncytial Virus bronchiolitis
}

\author{
Maha E. Omran ${ }^{1}$, Mohamed AE. Fahmy ${ }^{2}$, Manal M. Zaher ${ }^{3}$ \\ ${ }^{1}$ Microbiology and Immunology Department Faculty of Pharmacy (for Girls), \\ ${ }^{2}$ Medical Biochemistry Department Faculty of Medicine, ${ }^{3}$ Pediatric Department Faculty of \\ Medicine (for Girls) - Al-Azhar University
}

\begin{abstract}
Viral bronchiolitis is one of the leading causes for hospitalization of infants in the world and causes an estimated one million deaths per year worldwide. Respiratory syncytial virus (RSV) is associated with the majority of cases. During the last few years it has become increasingly clear that $\mathrm{T}$ cells contribute to the abnormal regulation of the immune response in viral diseases since these cells are potent producers of a large variety of cytokines. It was reported that cord blood interferon gamma (IFN- $\gamma$ ) responses were inversely related to the frequency of viral respiratory infections. To ascertain whether RSV infection promotes a different IFN- $\gamma$ profile to that induced by other respiratory infections, thirty-two infants with severe bronchiolitis were enrolled in this study. RSV-IgM was detected by immunofluorescent technique in 23/32 patients. Serum IFN- $\gamma$ levels in $\mathrm{RSV}^{+}$infants were significantly lower than $\mathrm{RSV}^{-}(\mathrm{p}<0.001)$. In vitro stimulation of peripheral blood cells followed by flow cytometery combined with intracellular cytokine staining revealed that both CD4+ and CD8+ cells contribute in IFN- $\gamma$ production. The percentage of $\mathrm{CD} 4+$ cells producing IFN- $\gamma$ in $\mathrm{RSV}^{+}$was significantly lower $(P<0.05)$ than those in $\mathrm{RSV}^{-}$, while the difference in \% of CD8+ between $\mathrm{RSV}^{+}$and $\mathrm{RSV}^{-}$was non significant. Our conclusions are that RSV infection is associated with severe decreased IFN- $\gamma$ responses. Both $\mathrm{CD} 4+$ and $\mathrm{CD} 8+$ cells contribute in IFN- $\gamma$ production during RSV bronchiolitis. RSV infection promotes a different IFN- $\gamma$ profile from that induced by other respiratory infections.
\end{abstract}

\section{Introduction}

Respiratory syncytial virus (RSV) is a non-segmented, single-stranded RNA virus belonging to the Paramixoviridae family (Collins et al., 1996). RSV infection is one of the main causes of respiratory illness worldwide. Almost all children become infected with RSV within the first 2 years of life (Avendaño et al., 2003) and $30 \%$ of them develop lower respiratory tract illness, including bronchiolitis, or respiratory failure (Holberg et al., 1991). The later is the reason for hospitalization in $0.5 \%-2 \%$ of the infected children (Collins et al., 1996; Leader and Kohlhase, 2002), and occasionally may lead to death in $1 \%$ of hospitalized children (Simoes, 1999; Hall, 2001).

Primary RSV infections in young infants are frequently manifested as bronchiolitis or pneumonia. In older children and adults, symptoms are usually restricted to the upper respiratory tract. Immaturity of the immune system in infants has been proposed as one of the reasons for the decreased virus-specific clearance (Everard and Milner 1992). Certain other underlying conditions reported to increase the risk of contracting and developing severe RSV disease including prematurity with or without bronchopulmonary dysplasia, congenital heart disease, immunosuppression, or another underlying respiratory condition (Collins et al., 1996). The difference between disease severity in previously healthy infants who are infected with RSV in the first year of life may be attributed to airway size (Young et al., 1995), high levels of passively acquired maternal IgG antibody (Everard and Milner 1992; Yamazaki et al., 1994) and consistent 
with these theories, the peak age of incidence for bronchiolitis is 2-4 months (Martinez, 1999). However, these factors cannot be the whole explanation for RSV bronchiolitis, as the majority of vulnerable infants exposed at the peak age do not develop the disease (Openshaw, 1995). Recent interest has therefore focused on the role of the host immune response in the pathogenesis of bronchiolitis.

More over, in some children with a genetic predisposition to atopic diseases, RSV infection has been related to the development of episodes of recurrent wheeze, bronchial obstruction and asthma (Stein et al., 1999; Sigurs et al., 2000; Legg et al., 2003; McNamara et al., 2004).

Immune responses range from a highly cellular (macrophage/cytotoxic $\mathrm{T}$ cell) response (Fitch, 1992) to a predominately humoral or antibody-mediated immunity (Berek, 1992). Cellular immunity has classically been described as the defense mechanism against viral infections. The development of cellular or humoral immune responses will depend on a repertoire of cytokines produced by numerous cells including CD4+ and CD8+ $\mathrm{T}$ cells. These lymphocytes can be subdivided into 2 subsets, T helper 1 (Th1) and T helper 2 (Th2), on the basis of the cytokine profiles they synthesize. Type $1 \mathrm{~T}$ cells produce interleukin (IL)-2, IL-12, interferon gamma (IFN- $\gamma$ ) and tumor necrosis factor (TNF)- $\beta$. IFN- $\gamma$ is an essential cytokine in the viral cell-mediated immune response which is associated with viral disease control and pathogen clearance (Pinto et al., 2006). IL-12, produced by monocytes and antigenpresenting cells, promote the differentiation of native CD4+ $\mathrm{T}$ cells to the Th1 phenotype and decrease the synthesis of the type 2 cytokines IL- 4 and IL- 10 by CD4+ T cells (Berek, 1992).

On the other hand, Th2 cells selectively produce IL-4, IL-5, IL-6 and IL10 that participate in the development of humoral immunity and have a prominent role in immediate-type hypersensitivity (Fitch, 1992). The significance of Th2 responses in natural RSV infections in humans remained unclear. Some studies demonstrated $\mathrm{Th} 2$ cytokine responses when natural infection occurred in children who went on to develop severe RSV disease (Renzi et al., 1997; Roman et al., 1997; Bendelja et al., 2000), whereas, in other studies, such a shift toward a Th2 response was not found (Bont et al., 1999; Brandenburg et al., 2000). It should be mentioned that the induction of a Th1 response does not necessarily exclude the presence of a concomitant Th2 response and its associated pathologic effects, because Th2 cytokines and Th1 cytokines can be detected simultaneously (Waris et al., 1997; Barends et al., 2002).

Although it was previously believed that CD4+ T cells exclusively provided the cytokine help to various "effector" cells, it is now known that CD8+ (or cytotoxic) $\mathrm{T}$ cells can also perform similar functions. Therefore, both $\mathrm{CD}^{+}$(T-helper) and $\mathrm{CD}^{+}$ (T-cytotoxic) cells are now recognized to have similar capabilities for production of type 1 and type 2 cytokines (Cho et al., 2002).

Recent studies suggest that $\gamma \delta \mathrm{T}$ cells play an important role in the immune response not only to bacterial infections such as tuberculosis (Saunders et al., 1998) but also to viral infections such as cytomegalovirus or Epstein-Barr virus infection (De Paoli et al., 1990; Déchanet et al., 1999). This hypothesis is compatible with the observation by Aoyagi et al., 2003 that the proportion of $\gamma \delta \mathrm{T}$ cells which produce IFN- $\gamma$ after mitogen stimulation is significantly reduced in patients with RSV bronchiolitis.

Several inflammatory cytokines have been detected in the airway of RSVinfected patients, including IL-2, (Giugno et al., 2004) IL-4 (Legg et al., 2003), IL-5 (Kim et al., 2003), IL-6 (Sheeran et al., 1999), IL-9 (McNamara et al., 2004), IL10, IL-12 (Legg et al., 2003), IL-18 (van Benten et al., 2003) tumor necrotic factor (TNF)- $\alpha$ (Hornsleth et al., 2001) and interferon (IFN)- $\gamma$ (Joshi et al., 2003; Legg et al., 2003). However, the mechanisms that are involved in airway inflammation in response to viral-induced bronchiolitis are not fully understood. Based on the current understanding of allergic diseases including asthma, these conditions are considered to 
arise from an irregular balance among $\mathrm{T}$ cell phenotypes. This entails not only a shift in the Th1/Th2 balance, but also includes the action of the regulatory $\mathrm{T}$ cells that play an important role in the pathophysiological response against various stimuli such as respiratory viruses and airborne allergens (Murai et al., 2007).

An attempt to develop a formalininactivated RSV (FI-RSV) vaccine during the 1960s resulted in an aggravated infection in immunized children, leading to hospitalization, while infection of nonimmunized children produced much milder symptoms. The reason for this remained an enigma, but gradually studies of RSV infection led to the suggestion that immunized persons developed allergy after immunization prior to RSV infection (Becker, 2006).

Interestingly, it was found that RSVinfected epithelial cells produce inflammatory cytokines that potently stimulate cortisol secretion (Willenberg et al., 2002) such as TNF- $\alpha$, IL- $1 \alpha$, IL-1 $\beta$, and IL-6 (Matsuda et al., 1995; Jiang et al., 1998). Glucocorticosteroids have a role in inhibiting the IFN- $\gamma$ response, acting directly on $\mathrm{T}$ cells or indirectly through IL12 (Blotta et al., 1997; Hu et al., 2003). In this way, an increase in plasma cortisol would induce also an imbalance between type 1/type 2 cells and their products with a shift toward a type 2 response. This finding should be taken into consideration when systemic steroids are prescribed to RSV-infected infants (Pinto et al., 2006).

It is not clear whether the reported cytokine imbalances are the result of an alteration in the distribution of specific Tcell subsets or whether intrinsic dysregulation in cytokine production is a characteristic of diseased individuals.

IFN- $\gamma$ is a multifunctional protein first observed as an antiviral activity in cultures of stimulated Sindbis virus-infected human leukocytes (Wheelock, 1965). It is produced by $\mathrm{T}$ lymphocytes and natural killer (NK) cells. IFN- $\gamma$ is now known to be both an inhibitor of viral replication and an immunoregulator of numerous immunological functions. IFN- $\gamma$ influences the class of antibody produced by B cells, upregulates class I and II MHC complex antigens and increases the efficiency of macrophage-mediated killing of intracellular parasites including viruses (Mogensen and Virelizier, 1987; Ijzermans and Marquet, 1989).

Current bioassays for IFN- $\gamma$ are usually based on measurement of its antiviral activity, e.g., using HeLa cells infected with encephalomyocarditis virus. These assays are time-consuming and not completely specific for IFN- $\gamma$. Determination of IFN- $\gamma$ levels by enzyme linked immunosorbent assay (ELISA) is more sensitive and specific since it employs the quantitative sandwich enzyme immunoassay technique (Däubener et al., 1994).

In vitro stimulation of peripheral blood cells with Phorbol 12-myristate 13acetate (PMA) and ionomycin results in activation for most of the cells, as confirmed by the expression of CD69, an early activation antigen. However, only a small percentage of cells did produce cytokines. The PMA and ionomycin stimulation appears to be consistent with the physiologically regulated cytokine expression and, when used for short periods of time, it only up-regulates the secretion of cytokines from cells with a defined cytokine pattern of expression (Picker et al., 1995).

We aimed, first, to determine the causative agent of bronchiolitis in specified group of Egyptian infants. Secondly, we sought to ascertain whether RSV infection promotes a different IFN- $\gamma$ profile to that induced by other respiratory infections. To accomplish this aim we determine the levels of serum IFN- $\gamma$ by ELISA. Also, we specify the type of T-lymphocytes that is contributed to IFN- $\gamma$ production by using flow cytometery technique combined with intracellular cytokine staining applied to in vitro stimulated peripheral blood cells to predict if there is shift in the Th1/Th2 balance or not.

\section{Material and Methods:}

\section{Subjects:}

Thirty-two infants (14 boys and 18 girls) aged 5 weeks to 10 months (mean 
22.13 weeks) hospitalized at Pediatric Department of Al- Zahraa University Hospital with severe respiratory illness and bronchial obstruction demonstrated by wheezing and/or hyperinflation on chest radiograph were enrolled in this study. All of them had no history of any significant pathology before, such as congenital heart disease, congenital respiratory disorder, immunodeficiency, chronic inflammatory disease, chronic lung disease after infantile respiratory distress syndrome, or immature infants of less than 2,500 $\mathrm{g}$ weight at birth. The clinical criteria applied to define severity of their illness were the respiratory rate, intensity of wheezing, the presence of cyanosis, the use of accessory of respiratory muscles, and the presence of oxygen requirement (Lukić-Grlić et al, 1999). The diagnosis of bronchiolitis was based on the clinical criteria of tachypnoea, coryzal symptoms and respiratory distress. None of the patients was in need of mechanical ventilation. None of them were treated with antibiotics or steroid when blood samples were collected. Bacteriological and other laboratory analyses which included quantification of C-reactive protein (CRP), erythrocyte sedimentation rate (ESR) and leucocyte count were performed for each infant to exclude possible non-viral infections.

\section{Blood Collection}

From each of all participating infants blood samples were collected in two tubes using butterfly: the $1^{\text {st }}$ in a serum separator tube (SST) and allowed to clot for 30 minutes before centrifuged for 10 minutes at approximately $1000 \mathrm{x} \mathrm{g}$ to separate serum which was divided into aliquots and stored at $-20^{\circ} \mathrm{C}$ until used for respiratory syncytial virus detection and IFN- $\gamma$ assay. The $2^{\text {nd }}$ portion was collected into evacuated sterile tubes containing heparin as anticoagulant. It was used for detection of IFN- $\gamma$ intracellular using flow cytometer.

\section{Respiratory Syncytial Virus detection}

(RSV)

The presence of RSV infection was detected by indirect immunofluorescent assay (RSV-IFA) kit for the diagnosis of
RSV IgM antibodies in serum according to the manufacture's instructions (Vircell, Spain).

\section{Control Group}

Nine out of 32 were RSV negative. Those were included as control group.

\section{IFN- $\gamma$ assay}

The concentration of IFN- $\gamma$ was determined in the serum using ELISA kit (Human IFN- Immunoassay, Catalog Number DIF50, Quantikine, USA). The limit of detectability was $8 \mathrm{pg} / \mathrm{mL}$. Samples that registered above the standard curve were diluted and reanalyzed. When values were below the detection threshold, the minimum detectable level was assigned.

\section{Venous blood processing and cytokine} induction (Bendelja et al., 2000)

RPMI-1640 (GIBCO BRL, Grand

Island, NY, USA) supplemented with $2 \mathrm{mM}$ L-glutamine, $100 \mathrm{IU} / \mathrm{ml}$ penicillin, 100 $\mu \mathrm{g} / \mathrm{ml}$ streptomycin and $2 \times 10^{-5} \mathrm{M}$ mercaptoethanol was used for double-fold dilution of the heparinized blood samples. A total of $500 \mu \mathrm{l}$ heparinized venous blood was diluted with $500 \mu 1$ of RPMI-1640 in sterile conical polypropylene tubes (Falcon, Becton Dickinson) and incubated prior to in vitro stimulation. Diluted blood $(200 \mu \mathrm{l})$ was stimulated by addition of $50 \mathrm{ng} / \mathrm{ml}$ PMA (Sigma, St Louis, MO) and 0.75 $\mu \mathrm{g} / \mathrm{ml}$ ionomycin (Sigma) in the presence of $10 \mu \mathrm{g} / \mathrm{ml}$ brefeldin A (BFA; Sigma) for $6 \mathrm{~h}$ at $37^{\circ} \mathrm{C}$ in the presence of $5 \% \mathrm{CO}_{2}$. After PMA and ionomycin stimulation, the samples were labeled with peridinin chlorophyll protein (PerCP)-conjugated anti-CD4, anti-CD8, and FITC-conjugated anti-IFN- $\gamma$ (Becton Dickinson, Heidelberg, Germany) MoAbs in the following combinations: anti-IFN- $\gamma /$ anti-CD4 and anti-IFN- $\gamma /$ anti-CD8. Isotype-matched controls (Becton Dickinson) were included.

\section{Staining procedure}

A slightly modified intracellular staining protocol described by Jason and Larned (1997) was used. In short, after stimulation, diluted whole blood was aliquoted in volumes of $50 \mu \mathrm{l}$, washed, and 
incubated in the dark for $15 \mathrm{~min}$ at room temperature with $5 \mu \mathrm{l}$ of MoAbs for surface markers. After washing in staining buffer (containing 1\% fetal calf serum (FCS), $0.1 \% \mathrm{NaN}_{3}$ and Dulbecco's PBS), the samples were fixed with a fixation buffer (containing 4\% formaldehyde in Dulbecco's PBS) for $30 \mathrm{~min}$ at $4^{\circ} \mathrm{C}$, washed and permeabilized with a permeabilization buffer (containing 1\% FCS, $0.1 \% \quad \mathrm{NaN}_{3}$, $0 \cdot 1 \%$ saponin in Dulbecco's PBS) for 15 $\min$ at $4^{\circ} \mathrm{C}$. Washing in the permeabilization buffer sufficed for erythrocytolysis. Then, $50 \mu \mathrm{l}$ of the permeabilization buffer were added to the cell pellet and incubated with fluorochrome-conjugated anti-cytokine MoAbs for $30 \mathrm{~min}$ at $4^{\circ} \mathrm{C}$. Then $1.25 \mu \mathrm{g} / \mathrm{ml}$ anti-IFN- $\gamma$-FITC was added. Finally, the stained cells were washed with permeabilization buffer and resuspended in $0.5 \mathrm{ml}$ of the staining buffer and immediately analyzed on a flow cytometer (FACSCalibur; Becton Dickinson, San Jose, CA).

\section{Detection of intracellular cytokine by Flow Cytometery}

Cell samples were analyzed using the CellQuest Software on a flow cytometer (FACSCalibur; Becton Dickinson, San Jose, CA). A correlated analysis of the forward and right-angle scatters was used to establish the lymphocyte gate. The threecolour analysis followed on obtaining 10000 cells in lymphocyte gate per sample.

\section{Statistical analysis}

The percentages of IFN- $\gamma$ producing cells were analysed by the Mann-Whitney $U$-test. Values of $P<0.05$ were considered significant.

\section{Results}

\section{Respiratory Syncytial Virus (RSV) detection}

RSV-IgM was detected by indirect immunofluorescent assay (RSV-IFA) in 23 out of $32(71.88 \%)$ of the studied infants. The first group was designated $\mathrm{RSV}^{+}$ $(n=23)$, while the second group was designated $\mathrm{RSV}^{-}(n=9)$.

\section{IFN- $\gamma$ assay}

The levels of serum IFN- $\gamma$ determined by ELISA technique in $\mathrm{RSV}^{+}$and $\mathrm{RSV}^{-}$ infants are shown in Figure (1), (medians, 25th-75th percentile ranges, and extremes). $\mathrm{RSV}^{+}$infants had median levels of serum IFN- $\gamma$ of $11 \mathrm{pg} / \mathrm{ml} \quad(4.25-12.75 \mathrm{pg} / \mathrm{ml}$ percentile ranges), range $(8-25 \mathrm{pg} / \mathrm{ml})$ significantly lower $(P<0.001)$ than $\mathrm{RSV}^{-}$ infants whose median levels of serum IFN$\gamma$ were $174 \mathrm{pg} / \mathrm{ml} \quad(76.25-228.75 \mathrm{pg} / \mathrm{ml}$ percentile ranges), range $(35-340 \mathrm{pg} / \mathrm{ml})$. only one sample was below the detection threshold $(8 \mathrm{pg} / \mathrm{ml})$ so the minimum detectable level was assigned.

\section{Determination of T-lymphocytes subsets producing IFN- $\gamma$ using flow cytometery}

To determine if the decreased amounts of IFN- $\gamma$ in the serum were the result of decreased number of $\mathrm{T}$ cells producing IFN- $\gamma$, we measured the percentage of $\mathrm{CD}^{+}$and $\mathrm{CD}^{+} \mathrm{T}$ cells expressing IFN- $\gamma$ as shown in Figure $(2 A)$, $(2 B)$, respectively. The mean percentage of $\mathrm{CD}^{+} \mathrm{T}$ cells expressing IFN- $\gamma$ obtained from $\mathrm{RSV}^{+}$infants was $(1.89 \%)$ with range of $(0.3-4.2 \%)$, significantly less $(P<0.05)$ than from $\mathrm{RSV}^{-}$infants $2.54 \%(0.5-5.7 \%)$ while, for the mean percentage of $\mathrm{CD} 8^{+} \mathrm{T}$ cells expressing IFN- $\gamma$, this was $2.5 \%$ (0.4$8.2 \%$ ) in $\mathrm{RSV}^{+}$infants, not significantly different from $\mathrm{RSV}^{-}$infants whose mean was $2.54 \%(1-5 \%)$. 


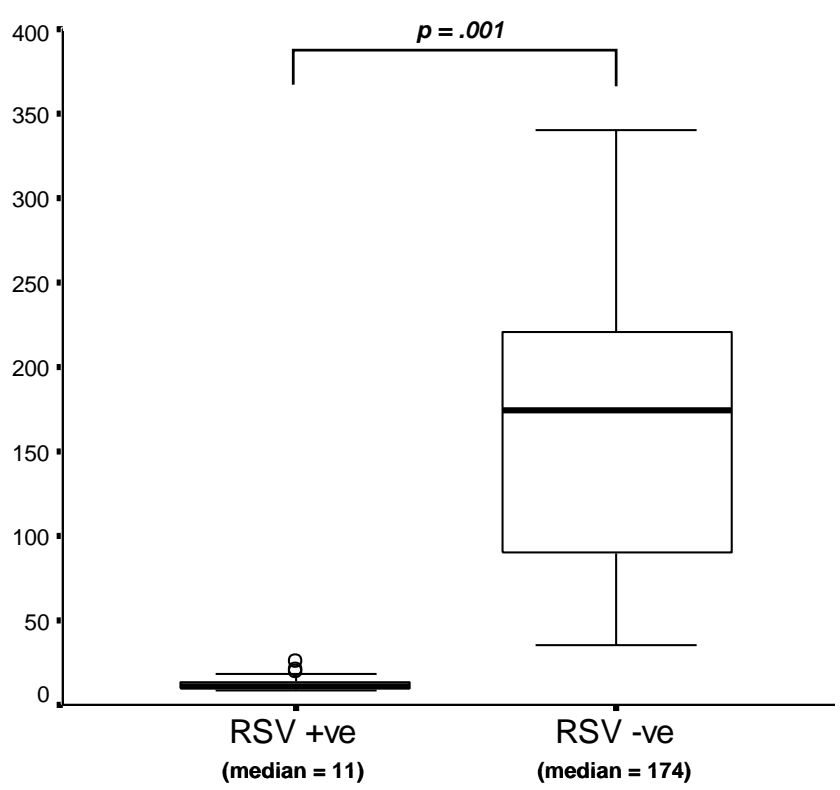

Figure (1). Levels of serum IFN- $\gamma(\mathrm{pg} / \mathrm{ml})$, medians, 25th to 75 th percentile ranges, and extremes from $\mathrm{RSV}^{+}$infants $(n=23)$ and $\mathrm{RSV}^{-}(n=9)$.

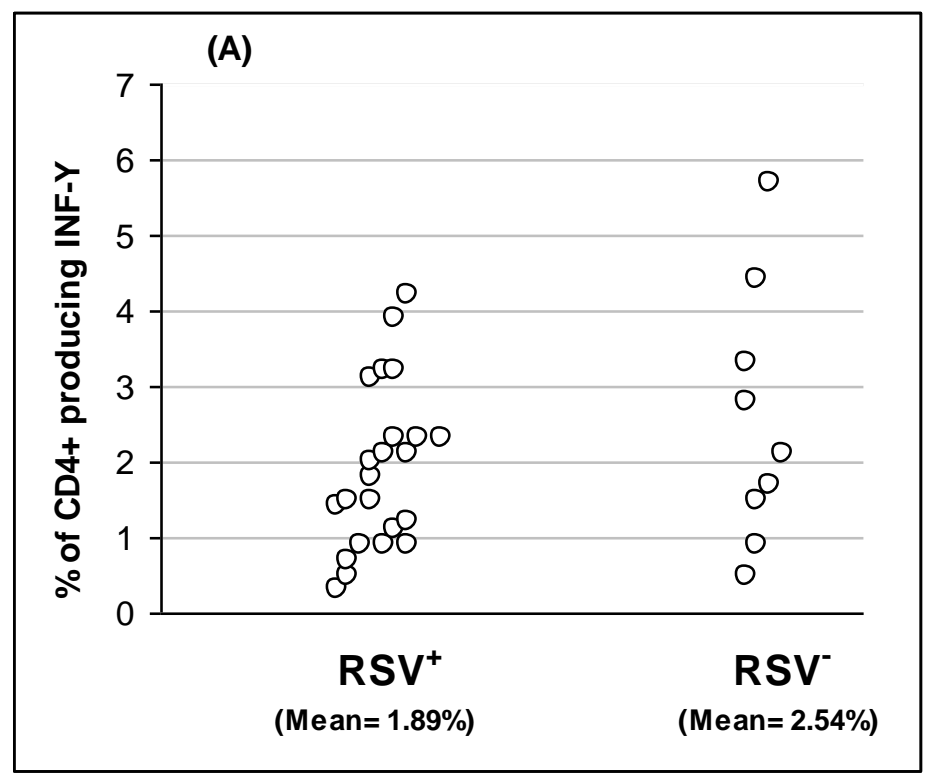

Figure (2 A).The percentage of $\mathrm{CD4}^{+}$lymphocytes producing IFN- $\gamma$, upon polyclonal stimulation with phorbol 12-myristate 13-acetate (PMA) and ionomycin for $\mathbf{R S V}^{+}$ infants $(n=23)$ and $\operatorname{RSV}^{-}(n=9)$. 


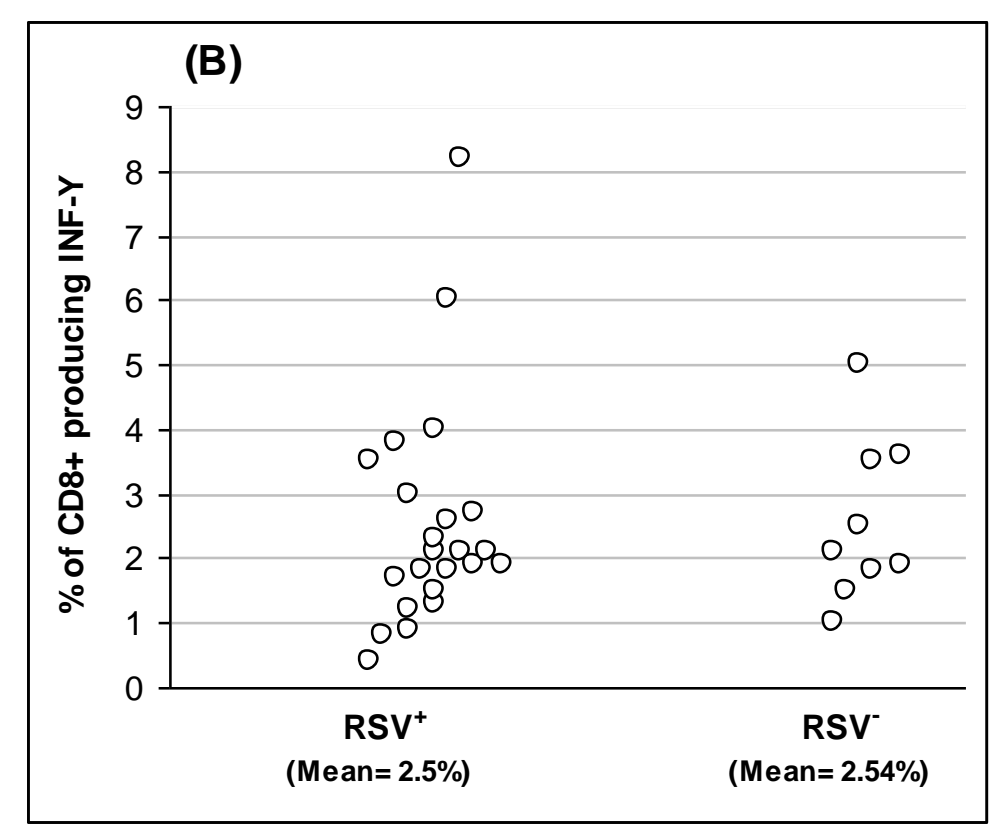

Figure $(2 \mathrm{~B})$.The percentage of $\mathrm{CD8}^{+}$lymphocytes producing IFN- $\gamma$, upon polyclonal stimulation with phorbol 12-myristate 13-acetate (PMA) and ionomycin for $\mathbf{R S V}^{+}$ infants $(n=23)$ and $\operatorname{RSV}^{-}(n=9)$.

\section{Discussion}

RSV bronchiolitis is partially an immune-mediated disease in which RSV-specific $\mathrm{T}$ cells play a predominant role (De Weerd et al., 1998). As our understanding of disease immunopathogenesis increases, so the potential benefits of appropriate immunotherapy become apparent. We have demonstrated the association of IFN- $\gamma$ response to RSV infection. IFN- $\gamma$ is the representative Th1type cytokine which suppresses the production of Th2-type cytokines and enhances cellular immunity (Scott, 1991; Maggi et al., 1992). IFN- $\gamma$ may play a protective role in RSV infections by diminishing viral replication (Chen et al., 2002), help in immunological clearance of the virus and high levels of IFN- $\gamma$ may be associated with lessening of the severity of infection (Aberle et al., 1999).

Our results showed that the level of IFN- $\gamma$ determined in serum samples of RSV-infected infants were significantly lower than that determined in serum samples of $\mathrm{RSV}^{-}$infants where another virus or no virus was identified as a cause of respiratory illness. These results are in agreement with the previous reports of decreased IFN- $\gamma$ secretion in RSV-infected infants either compared to healthy control group (Jackson and Scott, 1996; Román et al., 1997; Bendelja et al., 2000) or to infants infected with another respiratory virus rather than RSV (Joshi et al., 2003). On the other hand, in contrast to our results, there was a study reported that IFN- $\gamma$ was elevated in the serum of RSV-infected infants (Chen et al., 2002).

Regarding other studies which determined the level of IFN- $\gamma$ in nasopharyngeal aspirates (NPAs), tracheal aspirates or the supernatant of the cultured peripheral blood mononuclear cells (PBMCs), again there was discrepancy. Early studies have demonstrated a lower production of interferon in nasal washes during RSV infections when compared to other viral infections (Hall et al., 1978; McIntosh, 1978). On the other hand, Sheeran et al. (1999) found higher cytokine and chemokine concentrations in nasopharyngeal and tracheal aspirates obtained from RSV-infected infants. Murai and coworkers reported that there was no 
significant difference between $\mathrm{RSV}^{+}$and $\mathrm{RSV}^{-}$infants with respect to the levels of IFN- $\gamma$ detected in (NPAs) (Murai et al., 2007). PBMCs from infants with severe RSV illness were found to produce less IFN- $\gamma$ than mildly infected infants and than controls (Pinto et al., 2006).

A major disadvantage of the ELISA method is the unknown phenotype of the cells which produced the cytokines. In our study, we try to determine which lymphocyte subset present in the venous blood producing INF- $\gamma$ is affected more by RSV infection and so is accompanied by decreased INF- $\gamma$ production. We used intracellular cytokine staining to identify the phenotype of IFN- $\gamma$-producing cells. To minimize the amount of blood withdrawn from study infants and to avoid the potential influence of gradient separation on isolated cells, we used the modified whole blood activation method first described by Jason and Larned (1997).

We showed that $\mathrm{CD}^{+}$and $\mathrm{CD} 8^{+} \mathrm{T}$ lymphocyte subsets produced IFN- $\gamma$ in both groups $\mathrm{RSV}^{+}$and $\mathrm{RSV}^{-}$infants groups. The percentage of IFN- $\gamma$ producing $\mathrm{CD} 4^{+}$cells in $\mathrm{RSV}^{+}$infants was significantly lower $(\mathrm{p}<$ $0.05)$ than in $\mathrm{RSV}^{-}$infants. These results are in accordance to study of Bendelja et al. (2000) who found the $\mathrm{CD} 4^{+}$lymphocytes skewing into type 2 to be accompanied by decreased IFN- $\gamma$ production by these cells after short-term polyclonal stimulation in vitro.

In contrast to $\mathrm{CD}^{+}$, the $\mathrm{CD} 8^{+} \mathrm{T}$ lymphocytes produce IFN- $\gamma$ and exhibit a predominantly cytolytic activity for the elimination of viral and other intracellular pathogens (Kaufmann, 1995). Recent data show the $\mathrm{CD}^{+} \mathrm{T}$ cells to produce type- 1 and type-2 cytokines (Mossman and Sad, 1996; Meissner et al., 1997) and to modulate the humoral immune response (Maggi et al., 1994; Paganelli et al., 1995). We showed that $\mathrm{CD} 8^{+} \mathrm{T}$ cells contributed to IFN- $\gamma$ production during RSV infection. These findings are comparable to Bendelja et al. (2000). We showed that there was no significant difference between the percentages of IFN- $\gamma \mathrm{CD} 8^{+}$producing cells in $\mathrm{RSV}^{+}$and $\mathrm{RSV}^{-}$infants. This may support the concept that excessive lymphocyte mediated cytotoxic activity is not principally responsible for the pathology in respiratory syncytial virus bronchiolitis. This prediction is in accordance to a study which proved that there was a lack of RSV specific CTL responses in peripheral blood of immunocompetent RSV-infected children, suggesting an alternative method of induction of immunity or compartmentalisation of immune cells (Jeena et al., 2003). On the other hand, Chen et al. (2002) reported that the frequency of IFN- $\gamma$ expression in $\mathrm{CD} 3+\mathrm{CD} 8+$ cells was more frequent in RSV-infected than control infants.

The immunological mechanisms by which respiratory syncytial virus (RSV) contributes to the development of asthma are poorly understood. Defective IFN- $\gamma$ production by peripheral blood mononuclear cells (PBMC) has been reported to be correlated with the severity of RSV bronchiolitis and the subsequent development of asthma (Román et al., 1997; Aberle et al., 1999; Bont et al., 1999; Renzi et al., 1999). IFN- $\gamma$ is produced by many subsets of immune cells such as NK cells, $\alpha \beta \mathrm{T}$ cells, and $\gamma \delta \mathrm{T}$ cells (Christmas and Meager, 1990; Scharton and Scott, 1993). It is very important to clarify the source of IFN- $\gamma$ in RSV bronchiolitis, but there have been few studies of the cell source of IFN- $\gamma$ in the acute infectious phase in humans (Hussell and Openshaw, 1998; Bendelja et al., 2000). There was a novel suggestion considering the role of $\gamma \delta$ $\mathrm{T}$ cells in RSV bronchiolitis in terms of the development of respiratory allergy. This was built on certain suppressed IFN- $\gamma$ production pattern by $\gamma \delta \mathrm{T}$ cells in patients with acute RSV-positive bronchiolitis which was related to the subsequent development of recurrent wheezing (Aoyagi et al., 2003). Defective IFN- $\gamma$ production during acute viral infection played an important role in the development of postbronchiolitis wheezing, which was clearly demonstrated by Sorkness et al., (1999) in an animal model of postbronchiolitis airway hyperreactivity. Elucidating these mechanisms will provide useful information to be used for the 
prevention of asthma and the development of practical vaccines. On the other hand, little differences in the level of IFN- $\gamma$ between asthmatic and non asthmatic patients with RSV infection had been reported (Oh et al., 2002).

Further, it may prove useful to investigate whether other respiratory viruses causing bronchiolitis lack the RSVassociated property to skew the initiated immune response toward type 2 . It is suggested strongly that RSV is unique in terms of its strong effect on IFN- $\gamma$ production by $\gamma \delta \mathrm{T}$ cells, and provokes a relatively $\mathrm{Th} 2$-skewed immune response in comparison with other pathogens in the acute phase. This hypothesis is compatible with the observation by Hall et al. (1978) that interferon production in nasal washes in acute RSV infection is significantly lower than in influenza and parainfluenza virus infection. On the other hand, a recent comparison between adenovirus-infected and RSV-infected infants revealed that there was no significant difference in the level of serum IFN- $\gamma$ (Oda and Yamamoto, 2008).

\section{Conclusion}

We conclude that RSV infection is one of the most important viral bronchiolitis among Egyptian infants below one year. RSV bronchiolitis is associated with severe decreased serum IFN- $\gamma$ levels. Both $\mathrm{CD}^{+}$and $\mathrm{CD}^{+} \mathrm{T}$ lymphocytes contribute in IFN- $\gamma$ production during RSV infection with significant decrease in the percentage of $\mathrm{CD}^{+}$producing IFN- $\gamma$ compared with other types of bronchiolitis where another virus or no virus was identified as a causative agent. We have demonstrated the association of deficient type 1 cytokine response to RSV infection. This raises the possibility that treatments which restore the type 1-type 2 cytokine balance to the relative type 1 predominance will ameliorate RSV disease. Further studies are required to confirm these findings in other patient groups.

\section{References}

1. Aberle JH, Aberle SW, Dworzak MN, et al. (1999). Reduced interferon- $\gamma$ expression in peripheral blood mononuclear cells of infants with severe respiratory syncytial virus disease. Am J Respir Crit Care Med.; 160: $1263-8$.

2. Aoyagi M, Shimojo N, Sekine K, Nishimuta T, and Kohno Y. (2003). Respiratory syncytial virus infection suppresses IFN- $\gamma$ production of $\gamma \delta$ T cells. Clin Exp Immunol.; 131: 312-7.

3. Avendaño LF, Palomino MA, Larrañaga C. (2003). Surveillance for respiratory syncytial virus in infants hospitalized for acute lower respiratory infection in Chile. $J$. Clin Microbiol.; 41: 4879 -82.

4. Barends M, Boelen A, de Rond L, et al. (2002). Influence of respiratory syncytial virus infection on cytokine and inflammatory responses in allergic mice. Clin. Exp. Allergy; 32:463-71.

5. Becker Y. (2006). Respiratory syncytial virus (RSV) evades the human adaptive immune system by skewing the Th1/Th2 cytokine balance toward increased levels of Th2 cytokines and IgE, markers of allergy-a review. Virus Genes; 33: 235-52.

6. Bendelja K, Gagro A, Bace A, et al. (2000). Predominant type-2 response in infants with respiratory syncytial virus (RSV) infection demonstrated by cytokine flow cytometry. Clin. Exp. Immunol.; 121:332-8.

7. Berek, C. (1992). Humoral Immunity. in Encyclopedia of Immunology, I.M. Roitt \& P.J. Delves Ed., Academic Press Ltd. San Diego, CA.

8. Blotta MH, DeKruyff RH, Umetsu DT. (1997). Corticosteroids inhibit IL-12 production in human monocytes and enhance their capacity to induce IL-4 synthesis in $\mathrm{CD}^{+}$ lymphocytes. J. Immunol.;158: $5589-95$.

9. Bont L, Heijnen CJ, Kavelaars A, et al. (1999). Peripheral blood cytokine responses and disease severity in respiratory syncytial virus bronchiolitis. Eur Respir J.; 14:144-9.

10. Brandenburg AH, Kleinjan A, van Het Land B, et al. (2000). Type 1-like immune response is 
found in children with respiratory syncytial virus infection regardless of clinical severity. $J \mathrm{Med}$ Virol.; 62: 267-70.

11. Chen ZM, Mao JH, Du LZ, Tang YM. (2002). Association of cytokine responses with disease severity in infants with respiratory syncytial virus infection. Acta Paediatr.;91: 914-22.

12. Cho SH, Stanciu LA, Begishivili T, et al. (2002). Peripheral blood $\mathrm{CD} 4^{+}$and $\mathrm{CD}^{+} \mathrm{T}$ cell type 1 and type 2 cytokine production in atopic asthmatic and normal subjects. Clin. Exp. Allergy; 32: 427 -33.

13. Christmas SE and Meager A. (1990). Production of interferon-gamma and tumour necrosis factor-alpha by human $\mathrm{T}$ cell clones expressing different forms of the $\gamma \delta$ receptor. Immunology.; 71: 486-92.

14. Collins PL, McIntosh K, Chanock RM. (1996). Respiratory syncytial virus. In Fields BN, Knipe DM, Howley PM, editors. Fields virology, 3rd ed. Philadelphia, Raven Publishers. 1313-51.

15. Däubener $\mathbf{W}$, Wanagat $\mathbf{N}$, Pilz $\mathbf{K}$, Seghrouchni S, Fischer HG, Hadding U. (1994). A new, simple, bioassay for human IFN-gamma.J Immunol Methods; 68:39-47.

16. De Paoli P, Gennari D, Martelli P, Cavarzerani V, Comoretto R, Santini G. (1990). $\quad \gamma \delta \mathrm{T}$ cell receptor-bearing lymphocytes during Epstein-Barr virus infection. J Infect Dis.; 161: 1013-6.

17. De Weerd W, Twilhaar WN, Kimpen JL. (1998). T cell subset analysis in peripheral blood of children with RSV bronchiolitis. Scand J Infect Dis.; 30: 77-80.

18. Déchanet J, Merville $\mathbf{P}$, Lim A, et al. (1999). Implication of $\gamma \delta \mathrm{T}$ cells in the human immune response to cytomegalovirus. J. Clin. Invest.; 103: 1437-49.

19. Everard ML and Milner AD. (1992). The respiratory syncytial virus and its role in acute bronchiolitis. Eur J Pediatr.; 151: 638-51.

20. Fitch, F.W. (1992). Cell-Mediated Immunity. in Encyclopedia of Immunology, I.M. Roitt \& P.J. Delves Ed., Academic Press Ltd. San Diego, CA.

21. Giugno KM, Machado DC, Amantea SL, Menna Barreto SS. (2004). Concentrations of interleukin-2 in the nasopharyngeal secretion of children with acute respiratory syncytial virus bronchiolitis. J. Pediatr.(Rio J.); 80: 315-20.
22. Hall CB, Douglas RG Jr, Simons RL, Geiman JM. (1978). Interferon production in children with respiratory syncytial, influenza, and parainfluenza virus infections. J. Peds.; 93: 28-32.

23. Hall CB. (2001). Respiratory syncytial virus and parainfluenza virus. N. Engl. J. Med; 344:1917-28.

24. Holberg CJ, Wright AL, Martinez FD, Ray CG, Taussig LM, Lebowitz MD. (1991): Risk factors for respiratory syncytial virus-associated lower respiratory illnesses in the first year of life. Am. J. Epidemiol.; 133: 1135-1151.

25. Hornsleth A, Loland L, Larsen LB. (2001). Cytokines and chemokines in respiratory secretion and severity of disease in infants with respiratory syncytial virus (RSV) infection. J. Clin. Virol.; 21: 163-70.

26. Hu X, LI WP, Meng C, Ivashkiv LB. (2003). Inhibition of IFN-gamma signaling by glucocorticoids. J. Immunol.; 170 : 4833-9.

27. Hussell T and Openshaw PJ. (1998). Intracellular IFN- $\gamma$ expression in natural killer cells precedes lung CD8 $\mathrm{T}$ cell recruitment during respiratory syncytial virus infection. J Gen Virol.; 79: 2593-601.

28. Ijzermans JN and Marquet RL (1989). Interferon-gamma: a review. Immunobiology; 179: 456-73.

29. Jackson M and Scott R. (1996). Different patterns of cytokine induction in cultures of respiratory syncytial (RS) virus-specific human Th cell lines following stimulation with RS virus and RS virus proteins. $J$. Med. Virol.; 49:161-9.

30. Jason J and Larned J. (1997). Single-cell cytokine profiles in normal humans: comparison of flow cytometric reagents and stimulation protocols. J Immunol Methods.; 207:13-22.

31. Jeena PM, Ayannusi OE, Annamalai K, Naidoo P, Coovadia HM, Guldner $P$. (2003). Risk factors for admission and the role of respiratory syncytial virus-specific cytotoxic T-lymphocyte responses in children with acute bronchiolitis. S Afr Med J.; 93: 291-4.

32. Jiang Z, Kunimoto M, Patel JA. (1998). Autocrine regulation and experimental modulation of interleukin/6 expression by human pulmonary epithelial cells infected with respiratory syncytial virus. J. Virol.; 72: 2496 -2499.

33. Joshi P, Shaw A, Kakakios A, Isaacs D. (2003). Interferon-gamma levels in nasopharyngeal secretions of infants with 
respiratory syncytial virus and other respiratory viral infections. Clin. Exp. Immunol; 131: 143-7.

34. Kaufmann SE. (1995). Immunity to intracellular microbial pathogens. Immunol Today; 16: 338-42.

35. Kim CK, Kim SW, Park CS, Kim BI, Kang H, Koh YY. (2003). Bronchoalveolar lavage cytokine profiles in acute asthma and acute bronchiolitis. $J$. Allergy Clin. Immunol.; 112: 64-71.

36. Leader $S$ and Kohlhase K. (2002). Respiratory syncytial virus-coded pediatric hospitalizations, 1997 to 1999. Pediatr Infect Dis J.; 21: 629-32.

37. Legg JP, Hussain IR, Warner JA, Johnston SL, Warner JO. (2003). Type 1 and type 2 cytokine imbalance in acute respiratory syncytial virus bronchiolitis. Am. J. Respir. Crit. Care Med.; 168: 633-9.

38. Lukić-Grlić A, Baće A, Lokar-Kolbas R, et al. (1999). Clinical and epidemiological aspects of respiratory syncytial virus lower respiratory tract infections. Eur $J$ Epidemiol.;15: 361-5.

39. Maggi E, Giudizi MG, Biagiotti R, et al. (1994). Th2 like CD8+ cells showing B cell helper function and reduced cytolytic activity in human immuno-deficiency virus type 1 infection. J Exp Med.; 180: 489-95.

40. Maggi E, Parronchi P, Manetti R, Simonelli C, Piccinni MP, Rugiu FS, De Carli M, Ricci M, Romagnani S. (1992). Reciprocal regulatory effects of IFNgamma and IL-4 on the in vitro development of human Th1 and Th2 clones. J Immunol.;148: 2142-7.

41. Martinez FD. (1999). Role of respiratory infection in onset of asthma and chronic obstructive pulmonary disease. Clin Exp Allergy; 29: 53-58.

42. Matsuda K, Tsutsumi H, Okamoto Y, Chiba C. (1995). Development of interleukin 6 and tumor necrosis factor alpha activity in nasopharyngeal secretions of infants and children during infection with respiratory syncytial virus. Clin Diagn Lab Immunol.; 2: 322 -4.

43. McIntosh K. (1978). Interferon in nasal secretions from infants with viral respiratory tract infections. J Peds.; 93: 33-6.

44. McNamara PS, Flanagan BF, Baldwin LM, Newland P, Hart CA, Smyth RL. (2004). Interleukin 9 production in the lungs of infants with severe respiratory syncytial virus bronchiolitis. Lancet; 27: 1031-7.
45. Meissner N, Kussebi F, Jung T, et al. (1997). A subset of CD8+ $T$ cells from allergic patients produces IL-4 and stimulates IgE production in vitro. Clin Exp Allergy; 27: 1402-11.

46. Mogensen SC and Virelizier JL. (1987). The interferon-macrophage alliance. Interferon; 8:55-84.

47. Mossman TR and Sad S. (1996). The expanding universe of T-cell subsets: Th1, Th2 and more. Immunol Today; 17:138-46.

48. Murai H, Terada A, Mizuno M, Asai M, Hirabayashi Y, Shimizu S, Morishita T, Kakita H, Hussein MH, Ito T, Kato I, Asai K, Togari H. (2007). IL-10 and RANTES are elevated in nasopharyngeal secretions of children with respiratory syncytial virus infection. Allergol Int.; 56: 157-63.

49. Oda K and Yamamoto Y. (2008). Serum interferon-gamma, interleukin-4, and interleukin-6 in infants with adenovirus and respiratory syncytial virus infection. Pediatr Int.; 50: 92-4.

50. Oh JW, Lee HB, Park IK, Kang JO. (2002). Interleukin-6, interleukin-8, interleukin-11, and interferon-gamma levels in nasopharyngeal aspirates from wheezing children with respiratory syncytial virus or influenza A virus infection. Pediatr Allergy Immunol.; 13: 350-6.

51. Openshaw PJ. (1995). Immunity and immunopathology to respiratory syncytial virus: the mouse model. Am J Respir Crit Care Med.; 152: S59-S62.

52. Paganelli R, Scala E, Ansotegui IJ, et al. (1995). CD8+ lymphocytes provide helper activity for virus-infected patients with hyper-IgE. J Exp Med.; 181: 423-8.

53. Picker LJ, Singh MK, Zdraveski Z, Treer JR, Waldrop SL, Bergstresser PR, Maino VC. (1995). Direct demonstration of cytokine synthesis heterogeneity among human memory/effector $\mathrm{T}$ cells by flow cytometry. Blood.; 86: 1408-19.

54. Pinto RA, Arredondo SM, Bono MR, Gaggero AA, Díaz PV. (2006). T helper 1/T helper 2 cytokine imbalance in respiratory syncytial virus infection is associated with increased endogenous plasma cortisol. Pediatrics; 117: 878-86.

55. Renzi PM, Turgeon JP, Marcotte JE, et al. (1999). Reduced interferon- $\gamma$ production in infants with bronchiolitis and asthma. Am J Respir Crit Care Med.; 159: 1417-22.

56. Renzi PM, Turgeon JP, Yang JP, et al. (1997). Cellular immunity is activated and a TH-2 response is associated with early 
wheezing in infants after bronchiolitis. $J$ Pediatr; 130:584-93.

57. Román M, Calhoun WJ, Hinton KL, Avendano LF, Simon V, Escobar AM, Gaggero A, Diaz PV. (1997). Respiratory syncytial virus infection in infants is associated with predominant Th-2-like response. Am J Respir Crit Care Med.; 156: 190-5.

58. Saunders BM, Frank AA, Cooper AM, Orme IM. (1998). Role of $\gamma \delta$ T cells in immunopathology of pulmonary Mycobacterium avium infection in mice. Infect Immun.; 66: 5508-21.

59. Scharton TM and Scott P. (1993). Natural killer cells are a source of interferon $\gamma$ that drives differentiation of $\mathrm{CD} 4+\mathrm{T}$ cell subsets and induces early resistance to Leishmania major in mice. J Exp Med.; 178: 567-77.

60. Scott P. (1991). IFN-gamma modulates the early development of Th1 and Th2 responses in a murine model of cutaneous leishmaniasis. J Immunol.; 147: 3149-55.

61. Sheeran P, Jafri H, Carubelli C, Saavedra J, Johnson C, Krisher K, Sánchez PJ, Ramilo O (1999). Elevated cytokine concentrations in the nasopharyngeal and tracheal secretions of children with respiratory syncytial virus disease. Pediatr Infect Dis J.; 18: 115-22.

62. Sigurs N, Bjarnason R, Sigurbergsson F, Kjellman B. (2000). Respiratory syncytial virus bronchiolitis in infancy is an important risk factor for asthma and allergy at age 7. Am J Respir Crit Care Med; 161:1501-7.

63. Simoes EAF. (1999). Respiratory syncytial virus infection. Lancet; 354: 847-52.

64. Sorkness RL, Castleman WL, Kumar A, Kaplan MR, Lemanske RF Jr. (1999). Prevention of chronic postbronchioitis airway sequelae with IFN-gamma treatmt in rats. Am J Respir Crit Care Med.; 160: 705-10.

65. Stein RT, Sherrill D, Morgan WJ, Holberg CJ, Halonen M, Taussig LM, Wright AL, Martinez FD. (1999). Respiratory syncytial virus in early life and risk of wheeze and allergy by age 13 years. Lancet; 354: 541-5.

66. van Benten IJ, van Drunen CM, Koopman LP et al. (2003). RSV-induced bronchiolitis but not upper respiratory tract infection is accompanied by an increased nasal IL-18 response. J. Med. Virol.; 71: 290-7.

67. Waris ME, Tsou C, Erdman DD, Day DB, Anderson LJ. (1997). Priming with live respiratory syncytial virus (RSV) prevents the enhanced pulmonary inflammatory response seen after RSV challenge in BALB/c mice immunized with formalininactivated RSV. J Virol.; 71: 6935-9.

68. Wheelock EF. (1965). Interferon-like virus-inhibitor induced in human leukocytes by phytohemagglutinin. Science; 149: 310-11

69. Willenberg HS, Path G, Vogeli TA, Scherbaum WA, Bornstein SR. (2002). Role of interleukin-6 in stress response in normal and tumorous adrenal cells and during chronic inflammation. Ann N Y Acad Sci.; 966: $304-14$.

70. Yamazaki H, Tsutsmi H, Matsuda K, Naga K, Ogra PL, Chiba S. (1994). Effect of maternal antibody response in nasopharyngeal secretion in infants and children during primary respiratory syncytial virus infection. J Gen Virol.; 75: 2115-9.

71. Young S, O'Keeffe PT, Arnott J, Landau LI. (1995). Lung function, airway responsiveness, and respiratory symptoms before and after bronchiolitis. Arch Dis Child.; 72:16-24. 


\section{دراسة نمط إنتاج مضاد الفيروسات جاما أثناء الإصابة بالتهاب القصيبات بواسطة \\ الفيروس التنفسي (آر.ا.في) في الرضع في مصر}

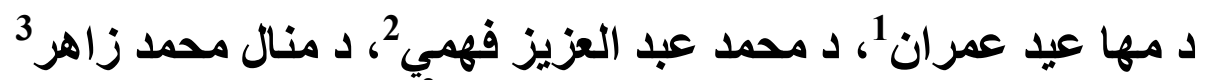

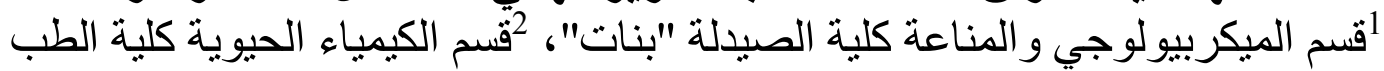

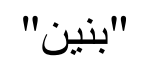

3قسم الأطفال كلية الطب "بنات"، - جامعة الأزهر

يسبب التهاب القصيبات الفيروسي احتجـاز الأطفال في المستشفيات و أيضـا مـا يقدر

بمليون وفاة سنويا في جميع أنحاء العالم. ترتبط معظم الحسالات بالفيروس التبات التفسي (آر.اس.في).

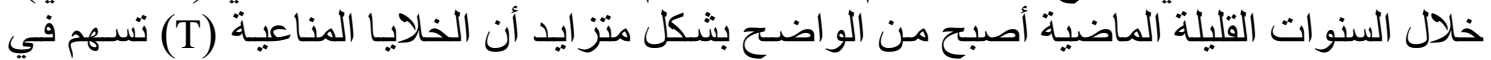

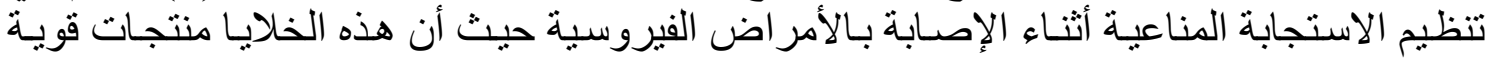

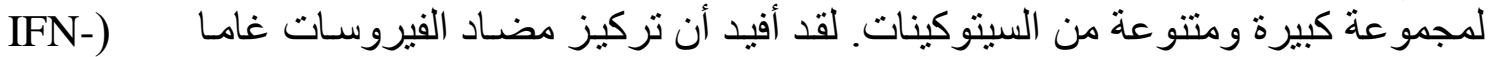

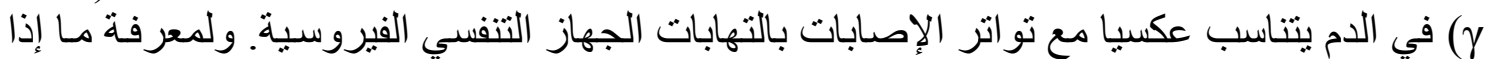

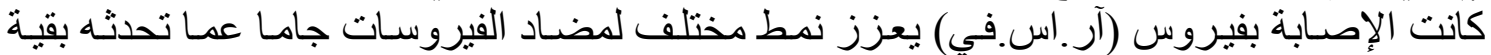

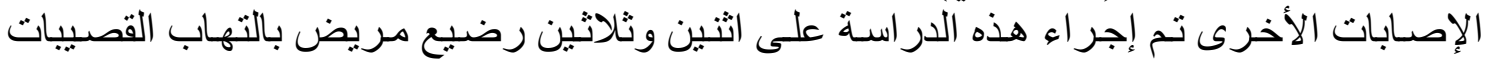

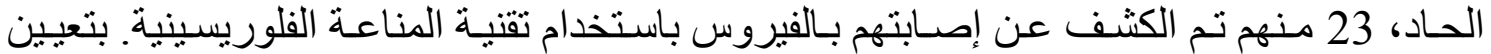

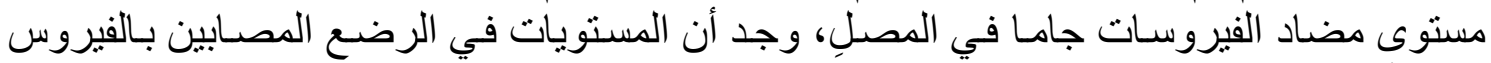

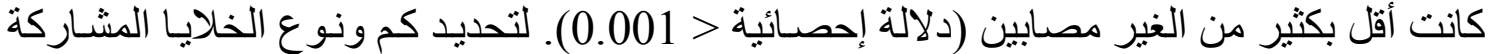

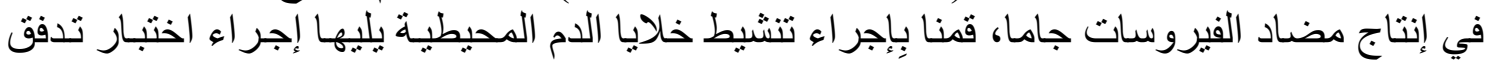

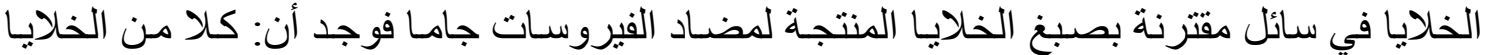

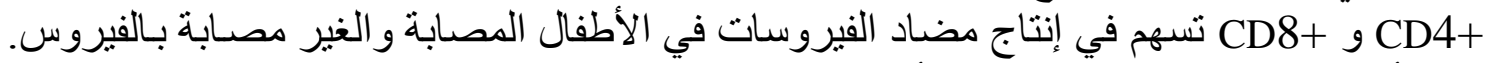

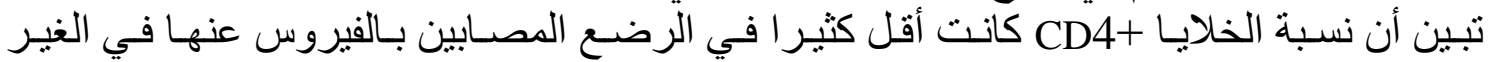

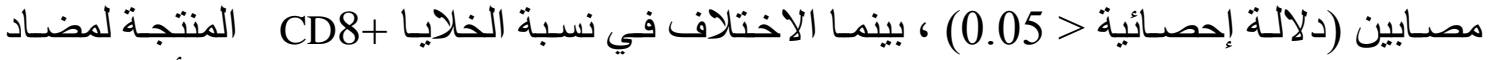

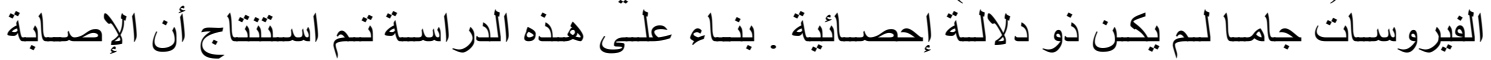

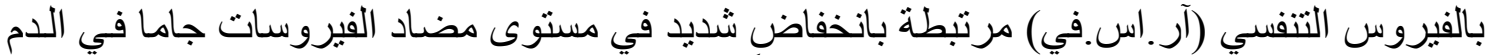

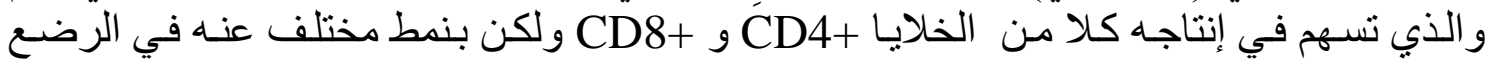

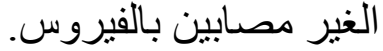

